\title{
"Waking the Feminists: Re-imagining the Space of the National Theatre in the Era of the Celtic Phoenix"
}

Emer O'Toole

\section{QUERY SHEET}

This page lists questions we have about your paper. The numbers displayed at left can be found in the text of the paper for reference. In addition, please review your paper as a whole for correctness.

Q1: Au: Please verify that author name and bio appears correctly.

\section{TABLE OF CONTENTS LISTING}

The table of contents for the journal will list your paper exactly as it appears below:

"Waking the Feminists: Re-imagining the Space of the National Theatre in the Era of the Celtic Phoenix"

Emer O'Toole 


\title{
"Waking the Feminists: Re-imagining the Space of the National Theatre in the Era of the Celtic Phoenix"
}

\author{
Emer O'Toole
}

\section{Waking the Nation}

In October 2015 Ireland's national theatre, the Abbey, announced its 2016 program, entitled Waking the Nation. 2016 constitutes the centenary of the Easter Rising and the proclamation of the Irish Republic-powerful political events that would culminate in Ireland's partition and the independence of the South from Britain. While the seeds of this moment lie in far deeper historical soil, birth of the nation rhetoric abounds in relation to 1916, and the centenary year was characterized by reflections on the history and current state of the Republic. It saw re-enactments, parades, processions, speeches, an outpouring of pride in Ireland's independence movement, as well as critical debates on Irish history and where the nation is headed next.

The Irish national theatre has long been understood as a "mirror up to nation" (Murray), due, in part, to its central role in the cultural nationalist movement that informed the Easter Rising. Though the first nationally endowed theatre in the English-speaking world, the Abbey is no mouthpiece for the state. For example, in 1926, just ten years after the Easter Rising, it staged Seán O'Casey's The Plough and the Stars, a tragi-comedy about 1916 that critiques blood sacrifice and laments the death of socialism in the Irish nationalist movement as well as the effect of the rising on women and protestants. The play provoked outcry from government officials, nationalists, and the relatives of those who died in the rebellion (Morash 163-71). Theatre scholar Patrick Lonergan notes that The Plough and the Stars firstly, "established that the function of the Abbey in an independent Ireland would be to analyze the nation's sense of itself," secondly, "allowed the Abbey to emphasize its importance to-but independence from-the new Irish state," and thirdly, "provoked a series of protests that were based on the belief that national theatre is worthy of serious debate and contestation" (62). This legacy remains vibrant today.

It was to be expected, therefore, that in announcing the Waking the Nation program, Fiach McConghaill, then artistic director of the Abbey, promised to "interrogate rather than celebrate the past" and encouraged Irish people, "in a year of national introspection," to "ask urgent questions 
about the safely guarded narrative of our nation" (www.abbeytheatre.ie, "Waking"). Arguably, it was also predictable that the centenary program showcased more writers by the name of Murphy than it did women. Ninety percent of the plays were written by men. Female directors did not fare much better: eighty percent of the plays were directed by men. As columnist Una Mullally noted in the Irish Times,

If the Abbey Theatre announced that 90 per cent of its 2016 programme was made up of plays written by women it would be viewed as extraordinary. It would be a 'statement.' Yet when the national theatre announced its programme celebrating the 1916 centenary, 90 per cent of the plays programmed are by men. That is not a 'statement,' it's just the norm.

If little interrogation of masculine domination in Ireland was present in the Abbey's centenary reflections, there was little distortion either. At the time the program was announced, $84 \%$ of Dáil Eireann consisted of men; $72 \%$ of voices on current affairs radio programmes were male voices (Walsh, Suiter and O'Connor 35); over 90\% of board members of Irish private companies were men (Barry 11); men comprised $79 \%$ of broadsheet byline writers (Deane and O'Mahony); $82 \%$ of those at professorial level at University were men (and there has yet to be a female president of any Irish university) (O'Connor 24-25); 87\% of produced screenplay writers in the Irish film industry were by men (Liddy 903); and men, of course, comprised $100 \%$ of bishops in the Catholic church, an organization that continues to have immense influence over Ireland's education and health sectors.

The Irish Republic faces into its second century at the same time as it climbs out of the economic recession that followed the Celtic Tiger, a recovery some call the Celtic Phoenix (The Economist). While the European Central Bank, the European Commission, and the German government have argued that Ireland's political commitment to the austerity measures imposed by the Troika in the wake of the crash have been central to its recovery, Samuel Brazys and Aidan Regan argue that it is more likely attributable to the cultivation of Foreign Direct Investment (FDI) in the technology sector by Irish political elites ("Capitalist Diversity"). Further, the narrative of economic progress under austerity, on which Enda Kenny's Fine Gael party sought to capitalize during the 2016 general election with the slogan "Keep the Recovery Going," was rejected at the ballot box, and Fine Gael was forced into an uncomfortable coalition with rival Fianna Fáil. This signals an awareness on behalf of the electorate, which can be backed up by empirical research (Regan and Brazys, "Phoenix"), that the "leprechaun economics" of Ireland's recovery benefit those within FDI sectors, many of whom are skilled EU workers, and leave low-to-middle income workers hit by austerity measures behind (9-29). Public sector and social welfare cuts have meant that austerity measures have disproportionately affected women, 
particularly working class women and lone parents (Spillane). Ursula Barry and Pauline Conroy show that gender equality policy was "a victim of the recession and crisis management of the Irish economy" (204).

This moment is indeed a time for national introspection. As Ireland "recovers," how can women challenge narratives of nation-cultural, economic, and political — that continue to exclude them? Drawing on theories of protest as performance and the performative re-constitution of space, this paper will introduce the feminist movement, Waking the Feminists (WTF), that arose in response to the Abbey's centenary Waking the Nation program. It will place the questions raised and the methods employed by WTF in the context of historic and ongoing struggles to articulate a place for feminism in the face of appeals, from enemies and allies alike, to ostensibly higher idealswhether appeals to aesthetic merit or economic recovery, appeals to class politics or republicanism-showing that the questions raised by WTF are important not only for women in Irish theatre, but for many feminist movements struggling to change patriarchal national and political narratives. It will confront what I term the "logic of lack" that justifies female exclusion from artistic and political movements through analysis of two contemporary femaleauthored theatre pieces, THEATREclub's Heroin and ANU Productions' Laundry, productions that undoubtedly "interrogate rather than celebrate" Ireland's past. Ultimately, I will argue that both WTF and the moment of recovery demand more than just recognition of female artists; they demand the restructuring of the architecture of the national theatre and the redistribution of its cultural capital to all the people of the nation.

\section{Waking the Feminists}

Fiach McConghaill might be considered an ally to the Irish feminist movement. For example, his 2016 Abbey conference program, Theatres of Change, was unmistakably and confrontationally pro-choice. Yet, when McConghaill was first questioned on the exclusion of women from his Waking the Nation program, he infamously responded (on twitter): “Them's the Breaks." He drew on a defense that combined the primacy of aesthetic merit over feminist concerns with what I call the logic of lack, which holds that work by women of sufficient aesthetic quality simply does not exist. He tweeted: "All my new play choices are based on the quality of the play, form and theme." Further, he claimed that decisions were not based on gender, but, rather, on, "who [he] admired and wanted to work with." The Waking the Nation program featured new work by David Ireland, Seán P Summers, and Phillip McMahon; it featured canonical work by Shakespeare, Tom Murphy, Frank McGuinness, and Seán O'Casey; it featured a play by Mutaz Abu Saleh about Israel and Palestine; and a staged reading of an adaptation by Jimmy Murphy. The only play by a woman was Ali White's Me Mollser, a 
monologue for children. Though the quality of White's work is not in question here, it is telling that women tend to be afforded more recognition in the Irish arts when the work is aimed at children. Mathematically speaking, the probability that a gender selection of $90 \%$ men would occur at random is very tiny (Prasad; Martin). Add the fact that the Abbey program was no anomaly, but representative of an Irish theatre scene in which men dominate the main stages and festival line ups, as well as an Irish public sphere in which men dominate media, politics, the arts, the academy and religion, and the failure of McConghaill's appeals to aesthetic integrity, and the logic of lack is clear to see.

Lian Bell, a freelance Dublin-based theatremaker, took to social media to issue a clarion call, while Maeve Stone, associate producer of Pan Pan Theatre Company coined the hashtag \#WakingtheFeminists (\#WTF), under which protest began to mobilize. Journalist Una Mullally articulated the anger women felt in a rallying column for The Irish Times. Others with media platforms, such as Belinda McKeon, Sara Keating, and Aoife Barry, followed her lead. Celebrities around the world, including Meryl Streep, Debra Messing, and Wim Wenders posed with signs showing their support. On social media platforms, on the airwaves, and in public discourse, the conversation and frustration continued to grow. In response to this furor, McConghaill and the Abbey apologized for the intemperate initial reaction, admitted that the 2016 program did not represent gender equality, and offered its stage for a public meeting to discuss the marginalization of women in Irish theatre. Five hundred tickets were sold in less than 10 minutes-the fastest selling show in Abbey history.

Performance scholar Baz Kershaw suggests the importance of dramaturgically analyzing popular protest. This requires alertness to both the aesthetic assumptions underlying radical action for social change and to what he terms the "knowing performativity" (91) of direct political action. If, to draw on Judith Butler, performative acts create what they name, performative acts of protest are deeply conscious of this creative force. Dramaturgies of protest have, of course, changed over time, and Kershaw asks for our attention to what different forms signify at "moments of crisis in history, when radical social and political change is, or appears to be, immanent" (92). It is perhaps telling that the WTF inaugural meeting was not only knowingly performative but also allied to performance in the theatrical sense; in taking to the Abbey stage the movement signalled consciousness of the power of representation, of the vital relationship between what is seen and what is believed.

The dramaturgy of the inaugural meeting showcased the maximum number of women's stories possible within its timeframe. Thirty invited speakers had 90 seconds each to share their observations about working as women in the Irish theatre. No one received a privileged time slot due to her prestige or place within the movement. Senator Ivana Bacik chaired, opening the event 
with remarks linking the lack of female voices on the Abbey stage with women's lack of visibility in public life. Lian Bell delivered WTF's mission statement: demands for sustained policies in achieving female inclusion in the arts, equal championing of female artists by Irish arts institutions, and economic parity for women working in the sector. Women's stories followed. If, as Kershaw suggests, we should look for the connections between dramaturgies of protest and moments in history when change appears to be immanent, then it is crucial to keep in mind that-as I argued above-at the moment of ostensible economic recovery the ideology of austerity is celebrated for its role in resuscitating the "Celtic Phoenix" while its deleterious effects are still felt by the majority of the population, and disproportionately by women. Change is certainly immanent, though the form it will take is uncertain: Ireland could become a two-tier society, where those working in favored FDI sectors live elite lives while the majority of the population live under neoliberal precarity (an economic and political arrangement which, Regan and Brazys argue, would be unstable, as many of the skilled workers in the tech industry are EU citizens who do not have a vote in Ireland); or the country could reject exclusionary national narratives, finally forging the feminist and socialist Republic by and for its people imagined by the 1916 proclamation.

Austerity, Helen Davies and Claire O'Callaghan remind us, is both a fiscal and ideological system, which "produces and enables socio-cultural politics as well as financial policies" (227). The archetypical values of this system, such as competition, the profit motive, and eradication of weakness, can be "coded as traditionally masculine" (227), while feminism's commitment to social justice is challenged by austerity's individualist and privilege blind logic. The dramaturgy of the meeting powerfully opposes this worldview, emphasising collectivity, community, equality, and-through personal testimony-the barriers to opportunity faced by those marginalized within the system. Its semiotics offer a rejection of a Republic for the few and not the many, implying an embrace of socialist feminism, which, in feminist theatre scholar Michelene Wandor's characterization, "proposes changes both in the position of women as women, and in the power relations of the very basis of society itself-its industrial production, and its political relations" (138). As director Laura Bowler pointed out at the meeting, when you only listen to half of the world, "you only get half the story." Speakers also addressed Ireland's lack of attention to regional and Irish language theatre. Many referred to the Abbey as "my" or "our" theatre, while actor Kate Gilmore gestured to the centenary as a symbolic moment at which real change can happen. The WTF meeting was not about slotting privileged women into traditionally male roles; it was about uncovering the other side of the national narrative; it was about restructuring the sector; it was about radical transformation and the validity of public claims on national institutions. 
Many of the feminist contributors to the event demonstrated a keen awareness of Kimberlé Crenshaw's observation that subordination is "frequently the consequence of the imposition of one burden that interacts with pre-existing vulnerabilities to create yet another dimension of disempowerment" (1299). Playwright Rosaleen McDonagh, a woman of Traveller ethnicity with a disability, spoke to the importance of preventing the replication of patterns of exclusion within feminist movements. Director Catriona McLaughlin reminded the auditorium that "being fair takes work" and encouraged people to look around and see who's missing - not only in terms of gender, but also in terms of other modes of marginalization. Black Irish dramatist Mary Duffin offered the affecting testimony that stories based on her life experiences will only be staged if she makes the characters white. Echoing the consciousness raising tactics of second wave women's movements, the contributions were personal. Women spoke with conviction, anger, and plenty of humor about the discrimination they have faced working in the Irish arts. Some, including veteran theatremakers Noelle Browne and Gina Moxley, spoke of the fear that speaking out would brand them, that men with power over whether or not they are cast or commissioned would not want to work with "difficult" women. Writer and actor Erica Murray, playwright Lisa Tierney-Keogh and actor Derbhle Crotty gestured to the innumerable talented women they know working in the theatre: a riposte to those who want to paint patriarchy as a meritocracy. Many explicitly tied the situation of women in Irish theatre to the position of women in the Republic. They noted the constitutional slurs on Irish women's autonomy, which enshrine their place in the home and deny them access to abortion; all thirty women spoke from the deep conviction and knowledge, which as an Irish theatre scholar I share, that women's work is of national importance too.

These intersectional, personal, and political critiques were underscored by the protest's use of space. Thirty chairs were arranged facing the auditorium, on which the speakers sat until it was their turn to take one of the podiums downstage left or downstage right. In a bold sense, this physically placed women artists centre of the hallowed stage from which they have been so excluded. In a more subtle register, it created two audiences, including all those in attendance in the dramaturgy of the protest. In her analysis of the global anti-capitalist movement, Sophie Nield interrogates the forms of space materialized by seemingly theatrical political interventions. She shows that activist theatre can inhabit "provocative borderlines," including those between "the real and the representational; and between dominant and resistant materialisations of the contemporary world" (53). Nield argues that "the battle is ultimately between two possible spaces: that imagined and produced by power in its domination and organisation of social activity, and that imagined, foretold and temporarily materialized in the theatrical moment of opposition"(53). If Ireland's patriarchal culture produced an Abbey in which men speak and women listen, WTF's protest temporarily 
materialized a space where women's stories were deemed to be of national importance too. The raucous auditorium, spatially framed as part of the spectacle, breaking into whoops and even, at the end, dance, implicated society-at-large in this temporarily materialized possibility. Further, the spatial framing of the audience troubled the relationship between representation and the real, drawing attention to the material work that needs to happen to make WTF more than just a theatrical gesture, to give the movement the radical potential to permanently transform the space of the national theatre, if not the nation.

\section{Waking the (Socialist) Feminists}

The centenary year also marked the implementation of a new political quota system to ensure that $30 \%$ of the candidates each Irish political party put forward for the general election were women. It was also a time when the campaign to Repeal the Eighth amendment, Ireland's constitutional ban on abortion, was in full swing. Drawing again on Kershaw, who asks us to find the links between dramaturgies of protest and actual or immanent social change, it is notable that WTF coalesced with Irish women demanding greater rights and representation on social and political stages. WTF also came at a time of renewed feminist vigor internationally (Cochrane). As Susan Faludi's work on feminism in the media has shown, these moments can create backlash. Our current political moment demonstrates that this backlash can come from both left and right of the political spectrum. It is no mystery how conservative factions react to gender quotas, abortion rights, or women playwrights. However, critique from ostensible feminist allies can be more insidious, positioning gender equality as a consideration secondary to the bigger picture of (as we have seen in relation to the Waking the Nation program) aesthetic integrity, but also to national, class, anti-austerity, or antiestablishment politics. The questions that are raised by WTF in terms of how women can gain access to the artistic, cultural and political movements of our nations are important not only for Irish women and artists, but for all socialist and intersectional feminists working at this time of frightening gains for the right and dismaying fracturing of the left.

Such questions are not new. We know that the marginalization of women within the New Left was part of the impetus behind the second wave of feminism (Evans 156-92), and that the insistence on the inclusion of women, queers and people of color fractured working class support for the US democratic party in the 1970s (Teixeira and Abramowitz 8-9). Similar issues have played out within academia and within feminist discourse for decades. For example, Christine Delphy, writing in the 1980s, insisted on an accessible materialist feminism that accounted for patriarchy, while Marxist Feminists Michèle Barrett and Mary McIntosh insisted that patriarchy was 
superstructural, and that the feminist mode of analysis adopted by Delphy excluded her from the project of Marxism. Delphy's defense feels almost as urgent today as when it was published in 1980. She says:

What bothers the left is when women apply to their own situation a materialist analysis; when they reject the ideology which says that they are naturally inferior or the victims of a culture which happens, unhappily but mysteriously (i.e. without any material benefits for anyone), to be sexist. But women are now saying 'there is no mystery: we are oppressed because we are exploited. What we go through makes life easier for others.' And the left is afraid that women will call a spade a spade, the economic economic, and their own sufferings exploitation. (100)

Delphy refuses to subsume her materialist analysis of gender oppression under a materialist analysis of capitalism. For her, these are different modes of oppression and have different beneficiaries; where capital exploits labor, men under patriarchy exploit women. She roundly condemns feminist theoreticians knitted to the letter of Marx who attest that addressing one mode of oppression will automatically erase another; she encourages vigilance against modes of thinking that hold women's liberation secondary to anti-capitalism.

Yet there are dangers to a feminism alienated from a holistic politics of the left. Work by Nancy Fraser and Angela McRobbie offers vital critiques of the kind of feminism arising in the ' 80 s that has, variously, distanced itself from socialism or been co-opted by capitalism. Frasers maps a shift of focus "from redistribution to recognition" (108) within feminism in the 1980s, concurrent with the rise of neoliberalism. She attributes this, in part, to the ways in which neoliberalism "changed the terrain on which feminism operated" (108) by recuperating feminist critiques of "bureaucratic paternalism" intended to transform state power into a vehicle of social justice (112), using them instead to legitimate marketization and state retrenchment. Writing following the global economic recession of 2008, at a moment of crisis for neoliberalism, Fraser is hopeful about the role of feminism in contesting what she terms the "successor society" (114). In explaining the "dangerous liaison" she maps between feminism and neoliberalism, she invokes the critique of traditional authority common to both (115), which, she argues, led the movements to converge. McRobbie, writing just before the moment of feminist resurgence to happen in the second decade of the twenty-first century, critiques the "postfeminism" of the 1990s and early 2000s, detailing the neat ideological trick whereby the language of feminism in terms of empowerment and choice was co-opted by neoliberalism, replacing structural critique with a narrative of agency as a "substitute for feminism" $(1 ; 24 ; 48 ; 155)$. She worries about "the suspension of the critique of capitalism that has always been such a defining feature of the tradition of socialist-feminist scholarship" (3).

While grateful for the valuable insights of Fraser and McRobbie, I remain skeptical that feminism and socialism have been disentangled to the degree 
they claim. If feminism has been less visible within the socialist movement, certainly socialism has been plainly legible within the feminist movement. In the columns of popular feminist media outlets, in publishing houses, and in the academy there are reams of writing and activism from the 1990s and 2000s challenging the co-option of feminism by capitalism and arguing against bourgeois, postfeminist, and antifeminist ideology. As I have argued above, WTF as a movement is informed by socialist ideals. As I will argue below, women's theatre work in Ireland is often intimately concerned with issues of class and economic inequality, and strives towards radical restructuring of social systems and social space. And yet much public discourse about WTF, as well as Mac Conghail's initial response to feminist critique, revolved around the need to avoid a politics of recognition: the need to avoid programming women just because they are women. It is very easy to invoke "identity politics" or the politics of recognition to delegitimize and misrecognize the structural nature of feminist critiques of under-representation as well as the extent to which women are already carrying out crucial political and creative work.

Further, if the rhetoric of feminism has found its way into popular culture in a somewhat superficial way, this potentially offers a base from which to recruit people to a more robust analysis. 1990s cultural products such as the pop group Spice Girls and the television show Sex and the City might function as "gateway drug" just as easily as "substitute." I also feel protective of the work of womanists, queer feminists, working class feminists and feminists with disabilities to ensure an intersectional politics, and am sensitive to the degree to which intersectionality is miscast as the politics of recognition by some historical materialists (see Bernstein 49-53). However, to the degree that feminism and socialism became disarticulated in the 1980s, 1990s, and early 2000s, it seems vital to acknowledge that there might be reasons that some feminists looked rightward that cannot merely be explained as a convergent critique of traditional authority: namely, abiding gender oppression inscribed at a fundamental ideological level on the left. For many Marxists and socialists, economic redistribution, which concerns the economic base, comes first, and the liberation of women, which is superstructural, is secondary. If real change comes from the base (the definition of which often fails to convincingly account for the domestic) then to insist on women's inclusion is to attack socialism with "identity politics," putting the good of one group before the good of all. Meanwhile, the neoliberal right, with its logic of individuality and meritocracy, becomes attractive to feminists precisely because, if it does not ideologically recognize the patriarchal causes of women's oppression, it does not slap feminist wrists when they insist on women's interests either. This is not simply about recognition; it is about redistribution. There is a significant body of evidence showing that women in positions of political power, whether left or right of 
the political spectrum, attend to issues affecting women and children substantially more than their male counterparts. Beth Reingold's review of this literature in the American context finds that "across time, office, and political parties, women, more often than men, take the lead on women's issues, no matter how such issues are defined" (130). This redistribution of political and economic resources from men to women is as important to many feminists as redistribution of political and economic resources from the bourgeoisie to the working class. More, it does not in any way preclude redistribution of resources to the working class. In fact, to the extent that women as a demographic are more left-leaning than men, it potentially encourages it.

In a hopeful article on the place of feminism in three emergent UK sites of antiausterity activism (Left Unity, The People's Assembly, and Occupy) Bice Maiguashca et al. identify:

increased presence and visibility of women and self-identified feminists in all three political spaces, the efforts of activists within each to engage with feminist theory and ideas - although notions of capitalism and class continue to dominate left discourse - and at the level of practice, the implementation of formal and informal policies/practices aimed at strengthening gender parity. (52)

Despite this conclusion, the descriptions of the organizations indicate that the work of creating a practically functioning feminist socialism is in its beginning stages. In all three of the case studies, the scholars found that gender oppression, patriarchy, and sexism were less than central to the groups' diagnoses of inequality and prescriptions for a better society. This is despite the particularly deleterious effects of austerity on gender equality and on women. Feminist concerns were often relegated to "safer spaces" policies, and lacking from press releases, founding statements, or official ideological visions. Also, the work of including feminist analysis in the movements often appears to be women's work (carried out in separate women's assemblies and caucuses) which, arguably, further marginalizes women from the central operations of the organizations, while also providing analytical labor to which the men (who numerically dominate) can gesture as evidence of equality. In short, even while Maiguashca et al. find an increased feminist presence and ideology on the left, it is clear that this ideology is secondary to what many socialists and Marxists quite simply see as the bigger picture. Perhaps we have not really come so far from the moment in the 1960s where the women's movement emerged from the New Left. Like nationalist narratives, like Mac Conghail's Waking the Nation program, like Ireland's story of recovery, and, of course, like patriarchy, contemporary socialism positions women as secondary. In the meantime, socialist commitment to radical restructuring of material conditions is integral to some of the most exciting female-authored theatre work being made in Ireland. Perhaps, ultimately, women's access 
to the space of the national theatre means significantly changing the space of the national theatre, and perhaps, ultimately, it is women's work that can do this.

\section{Women's Work}

According to the logic of McConghaill's initial defense, Irish female artists of sufficient quality and national importance weren't excluded from the centenary program, they simply didn't exist: they were lacking. Doreen Massey points out that space and the feminine are "frequently defined in terms of dichotomies in which each of them is most commonly defined as lack" (73) women are castrated; space is empty. Yet, the dramaturgy of the inaugural WTF meeting showed the power of manipulating space to make women appear. Thematically, the meeting was characterized by a strong sense that while the work on the Abbey stage is branded as important, the most exciting work is happening, just happening elsewhere.

This is one contention of the WTF movement that has met with much skepticism in public discourse in, for example, the comment threads beneath newspaper articles on the movement. "If Irish women are so good at making theatre, why haven't I heard of any Irish female theatremakers?" seems to be the refrain. Answering this is important, because WTF needs the public to attend work by women if its objectives are to be realized. For the skeptical, then (and in the awareness that academic attention confers cultural capital) I offer two case studies of contemporary Irish theatre for consideration in the context of 2016, productions which might also be read as dramaturgies of protests; productions which thread discourses of class and gender through the national narrative; productions which speak to Ireland's history, but gain even more urgency as Ireland's recovery narrative threatens to overwrite the ongoing effects of austerity on society's most vulnerable.

First, take Heroin (2010), directed by Grace Dyas. Dyas is a founding member of THEATREclub, an experimental company that works with marginalized groups to produce aesthetically challenging and politically provocative work, the dramaturgy of which is in itself a kind of protest against both oppression and the kind of art that perpetuates or ignores it. In 2009, Dyas began two years of workshops and outreach with recovering and current addicts at the Rialto methadone clinic. Dyas saw clear throughlines between economic and social deprivation, sexual abuse, failed social housing projects, and drug addiction. She felt there was a story the public simply did not understand in terms of how planning and infrastructure created and then ossified the problem. A theatre piece, Heroin, emerged to tell the story of heroin addiction in Ireland over the last five decades. This process of making-community-engaged, generating creative material collaboratively with demographics that have a lived stake in the material-itself disrupts what Davies and O'Callaghan locate as traditionally 
masculine "archetypical values" of austerity. What Rustom Bharucha calls in a postcolonial vein "the cult of the maestro" (40)-that is, the Western elevation of the artist to a godlike status because of his (and I use the male pronoun deliberately) supposed individual genius and the concurrent relegation of complex communally authored and sustained artwork to the status of raw material for his experiments-is challenged by work like Heroin, which rejects the notion of sole authorship. Dyas often contradicts attempts to single her out as the author of theatre pieces she has directed or co-directed, pointing to her fellow artists in THEATREclub as well as to the contributions of workshop collaborators.

The aesthetic content of the work mirrors the politics of the production process. The task of telling the story of addiction in Ireland over five decades is a daunting one, and, rather than writing a well-made play to present a coherent and comprehensive narrative, Dyas and her collaborators created an experimental dramaturgy that foregrounded the impossibility of painting the full picture. Three interrelated timelines played out at once. First, the three actors, Barry, Ger, and Lauren, were involved in a game. Barry tried to tell the story of Heroin addiction in Ireland, getting the others to help him; Ger was required to do everything Barry said, while Lauren could do anything she liked. This game created an affective sense of the futility of trying to keep a narrative, a purpose, or a life together when faced with architecture that by its nature disallows it. The production also displayed a keen intuitive grasp of Henri Lefebvre's observation that to change the social you must change space (289-91). The three actors built the set on stage each night, starting with a bare stage and slowly enclosing themselves in a ramshackle apartment. This was THEATREclub's attempt to represent the impact of design on the situation. The third and final timeline was that of addiction, which often follows a pattern of experimentation to initiation to isolation. These three timelines manifested and interwove with each other differently every night, but, like addiction, followed a familiar pattern, ensured by fatalistic structures. Drawing on George Ikishawa, Augusto Boal notes that

The bourgeois theatre is the finished theatre. The bourgeoisie already know what the world is like, their world, and is able to present images of this complete, finished world. The bourgeoisie presents the spectacle. On the other hand the proletariat and the oppressed classes do not know yet what their world will be like; consequently, their theatre will be the rehearsal, not the finished spectacle. (120)

Heroin's experimental dramaturgy offers its audiences a piece that can never be fully finished; the frustration of the actors/characters as they operate within eternally unwinnable games confronts not only Ireland's ongoing crisis of addiction, but also a bourgeois complacency that expects mimetic order, not aesthetic challenge. Heroin temporarily materializes not the utopian spaces found by Nield in Occupy's theatrical interventions, but, rather, 
an argument in space and time that gives form to the problem and stages the necessity of new spaces, new rules, a new Republic.

Heroin was made in the depths of the recession, about people whose lives the economic boom never touched, about people who are certainly now being left behind as official Ireland celebrates its recovery; it is work that combines an Aristotelian fatalism with a shrewd social conscience: the situation has been designed, not by uncaring Gods, but by mundane civil engineers. It is inherently a piece about the project of the Republic of Ireland, true to the experimental nature of the Abbey's roots. As Ireland recovers, Heroin might compel audiences to pay attention to those eternally excluded from the narrative of nation. The piece also offers some evidence as to why work by women is deemed "not ready" for the national stage. If ready means work by a sole maestro, work finished for Bourgeoise consumption, THEATREclub consistently challenges the very definition of nationally important art. Is the Abbey for all the children of the nation, or, like the Republic celebrating its economic recovery, are its benefits for a privileged class? Whose stories are told at the national theatre? Who feels welcome to participate? If we are honest in our answers to these questions, it becomes clear that encouraging work like THEATREclub's is not just about representation; it is about redistribution.

Second, let's consider Lisa Lowe's work Laundry (2011). Lowe's sitespecific theatre company ANU Productions makes innovative use of space and place to immerse audiences in social worlds and Irish histories that exist beneath the public consciousness. Based in a working class area of Dublin's North Inner City known as the Monto, ANU animates the urban environment in ways that are interdisciplinary, collaborative, and committed to active spectatorship. As Brian Singleton argues, what singles ANU's work out from other site specific companies is "their engagement with the social history of the sites they choose to revisualise and reanimate" (23), an engagement in which the site becomes a "social archive" (23). Bringing their often middle class theatre audiences into these working class areas has a provocative politics, which, Singleton argues, resists asserting the authority of the theatrical over the environment (35); Singleton points to a "sense of ownership of the area by the community, including all activity, social, antisocial or theatrical that occurred there" (35) as well as the propensity of residents to write themselves into the production (35). Like Heroin, this is work that confronts bourgeois theatre with its own biases, necessary work as the narrative of recovery threatens to blinker those set to benefit from Ireland's FDI sector to intersectional modes of exclusion.

Laundry brought spectators into a building in the Monto that had been used as a Magdalene Asylum. ${ }^{1}$ Lowe's piece blended performance art and installation with intimate, sometimes one-on-one performances and real testimonies, confronting audience members with choices and rendering them complicit in the fate of the 
women: would they help the penitents; would they listen to them; would they remember their names? Miriam Haughton, in her detailed examination of the landmark production, suggests that representation and the performance of silence function as strategies of power in Laundry. She argues that the "silencing of outcast women supported the representation of pure Irish womanhood that was critically bound up with the representation of the Irish state" (68) and, further, that the production succeeds "not only in its interrogation of past wrongs but in its realisation of present wrongs" (90). These functions map neatly onto McConghaill's professed aims for the Waking the Nation program. It might be argued, of course, that if the functions of the work map neatly onto the Abbey's centennial aims, the nature of the site specific and immersive dramaturgy is harder to align with its architecture. Here I am reminded of Catriona McLaughlin's important statement at the WTF inaugural meeting: being fair takes work. While a bourgeois feminism, defined by Wandor as the kind of feminism that "accepts the world as it is, and sees the main challenge for women as simply a matter of 'equalling up' with men" (136), might see the challenge of equality in the Irish arts as simply inserting female artists into conservatively individualist auteur roles and bourgeois spaces, a socialist feminism demands systemic change. We need to understand how the institution of the national theatre can evolve to encompass some of the most important women's work happening in the Republic. Whether reimagined for the space of the Abbey or forming part of the program while retaining its site specificity, a work like Laundry might have reminded the audience that 2016 marks another anniversary of immense importance to the Republic: the $20^{\text {th }}$ year since the closure of the last Magdalene laundry. Haughton observes, "It is interesting to note that, in the early days of independence, the nation was referred to as the Irish 'Free' State. Evidently, some sections of society enjoyed this new national freedom, whereas others were hidden, silenced, and imprisoned" (90). Surely work of this quality, commemorating the fate of those abused by an independent Ireland in the name of self-representation might befit a moment of national introspection. Certainly, I would be more convinced of this logic than of the Abbey's decision to stage Othello because the tale of femicide is, apparently, a "state of the nation" play. And, while I am delighted that Waking the Nation program chose Mutaz Abu Saleh's play, "New Middle East," increasing the diversity of the program and making links between Irish occupation and ongoing modes of colonialism, it seems pertinent to note the play's description in the Abbey's promotional material:

A masked soldier stands beside an open pit. He is burying a woman alive. The soldier is fulfilling his duty and the woman must be his victim.

Who is he? Who is she? What has she done?

(www.abbeytheatre.ie, "New Middle East")

With all this symbolic femicide being used to interrogate the state of the nation, surely there is a need to acknowledge the actual violence that independent Ireland 
has enacted on women's bodies. At the very least, Laundry speaks to the presence of visionary female theatremakers who might have been commissioned to reflect the history and present of the nation in 2016.

In considering the deeply political, historically engaged, aesthetically daring art made by women in Irish theatre, art which foregrounds the experiences of the marginalized, art which seems to prove that in asking for female representation we are asking not merely for recognition but for structural change and redistribution, it becomes apparent that WTF is more than a protest about the exclusion of women from the Abbey's centenary programme. It is also an interrogation of women's place in Irish history; it is a meditation on how women were written out and how they can regain access to the artistic and political movements of their eras and nations. If prosperity is once again in store for Ireland, WTF asks: prosperity for who? How can the egalitarian ideologies of feminism shape the next century of the Republic?

\section{WTF just Happened}

Women were integral to the artistic and administrative early years of the Abbey, just as they were integral to Ireland's independence movement. Yet, for many feminists of the time, the national question took precedence over the women's question (Ward; Cullen-Owens). Without a united women's movement to insist on the project of women's liberation as equal to the project of Republicanism, "post-partition Ireland was able to implement, with little resistance, highly reactionary policies in relation to women" (Ward 35). The feminist conviction that freedom from the colonizer and Gaelic revival would mean gender equality was proved false, and, as too often happens after a revolutionary moment in which socialists, feminists, and other artists are a driving force, post-independence Ireland was co-opted by a repressive, religious right. In 1937, the Irish constitution, Bunreacht na hÉireann, enshrined both the special place of the Catholic Church within the Irish state and the special place of Irish women in the home. Female revolutionaries were written out of history. Single mothers were incarcerated in state-funded, church-run laundries. Married women had to leave state jobs. And between the years 1934 and 2014 only an estimated 1\% of the plays on the Abbey's main stage were female-authored (Lonergan, "Women Writers"). The theatre once again held a mirror up to the Irish nation.

WTF arose in response to this male domination of Irish theatre and Irish society. Happening at a time in which austerity (the archetypical values of which can be coded as traditionally masculine) continues to victimize society's vulnerable even while global institutions and Irish politicians celebrate the Celtic Phoenix, WTF refuses to pretend that women, the working class, and other marginalized demographics have risen from the ashes; rather, 
the movement challenges these masculine values and the neoliberal threat of a new kind of divided Ireland. WTF is not only about recognising female artists, but also about redistribution of cultural capital and the restructuring of public institutions. The dramaturgy of the initial meeting emphasized collectivity and barriers to inclusion, countering faux-meritocratic claims of austerity and neoliberalism. It temporarily materialized an intersectional feminist space within the national theatre, and, to the extent that the Abbey is the nation's mirror, within the Republic.

Linking the exclusion of women from the (in many ways anti-hegemonic) Waking the Nation program with the exclusion of women from national and political movements, I explored the extent to which feminist demands for structural change are miscast as mere demands for recognition or even special treatment. I hope the dangers of this for socialist and artistic movements are apparent. As the right adopts an alluring language of faux-feminism, the left is weakened by failing to recognise intersections of class and gender; as artistic movements and institutions continue to define merit as masculine, they become aligned with neoliberalism and disarticulated from the projects of interrogation that they profess, and which, I would argue, make art valuable to a nation, relevant to citizens, and a force for speaking truth to power.

Tracing uses of space in Heroin and Laundry uncovers cutting analyses of class and gender: the dramaturgies of these pieces function as a kind of performative protest, rejecting the semiotics of bourgeois theatre spaces, foregrounding the impact of design on gender and class inequality, and decentring the neoliberal agent of the "maestro," whose ostensible genius merits his privilege. Making space for these kinds of productions does not just mean a women's name on the publicity posters; it means an entirely different kind of national theatre.

In the wake of the inaugural meeting, the Abbey promised to redress the gender imbalance in its 2016 program by staging female artists in its Autumn/Winter season. This program included Dyas's Heroin. When WTF met on November 14 2016, a year after the first explosive meeting, Bell recounted the movement's successes: the Abbey has committed to guiding principles on gender equality that set a new national and international standard; a member of the Waking the Feminists team is now serving on the Abbey board; the Arts Council has funded research into women and the arts, meaning that the personal stories shared at the first meeting can now be backed up with statistics, and progress towards equality will be measurable. Waking the Feminists has also liaised with other major arts and theatre companies and institutions beyond the Abbey. On November 29, 2016, the Abbey, under the new artistic directorship of two men, Neil Murray and Graham McLaren, announced its 2017 program. Fifty percent of the directors were women. Female writers fare less well at just under 20 percent. Nonetheless, it is certainly an improvement, and the Abbey has committed 
to achieving equality by 2020 . Given the current gendered power structures in Irish theatre, that would be revolutionary.

What really excites me about these developments is not just women's representation in the arts (although this is undoubtedly a step towards greater equality in and of itself) but the faith I have that greater women's representation will lead to an Abbey that serves the many, not just the privileged few. If the dramaturgy of the WTF protest and the work of ANU and THEATREclub are indicators of what is to come, I can imagine a national theatre which actively challenges masculine austerity ideology, sexism, classism, patriarchy, racism, and ableism, while pushing at the aesthetic boundaries of what theatre art can be and the social boundaries of to whom it can and should speak.

The year of WTFs extraordinary energy came to an end in November 2017, and the activists who spearheaded it stepped down to focus on their own art and their lives. If the promises that were made hold, and WTF manages to achieve gender equality in this one Irish institution, in this one symbolically vital area of Irish society, and in just five years, imagine what else is possible. The Abbey Theatre is a mirror up to the Irish nation, so what would it mean if it held an image of an equal society? In 1916, the proclamation spoke of equal rights and opportunities to all Irishmen and Irishwomen. When I asked one of those women, Grace Dyas of THEATREclub, what she wanted to happen in the next 100 years of the Irish Republic, she said: "I want it to happen. At all. It hasn't actually started yet. There hasn't been a Republic." WTF offers hope that it might finally be starting.

\section{Notes}

1. Magdalene Asylums for unmarried mothers or other "fallen women" were institutions in which penitents were incarcerated and worked, unpaid, in industrial laundries run by the Catholic Church but supported, the McAleese report confirmed in 2013, by state structures.

\section{Works Cited}

Abramowitz, Alan, and Ruy Teixeira. "The Decline of the White Working Class and the Rise of a Mass Upper-Middle Class.” Political Science Quarterly 124.3 (2009): 391-422. Print.

Barrett, Michele, and Mary McIntosh. "Christine Delphy: Towards a materialist feminism?" Feminist Review 1 (1979): 95-106. Print.

Barry, Ursula. "Policy on Gender Equality in Ireland Update 2015." Policy Department C: Citizen's Rights and Constitutional Affairs. Brussels: European Parliament. Sept. 2015. Print.

Barry, Ursula, and Pauline Conroy. "Ireland in Crisis 2008-2012: Women, Austerity and Inequality." Women and Austerity: the economic crisis and the future for gender equality. Ed. Maria Karamessini and Jill Rubery. Oxon; New York: Routledge, 2013. 186-206. Print.

Bernstein, Mary. "Identity Politics.” Annual Review of Sociology 31 (2005): 47-74. Print. 
Brazys, Samuel and Aidan Regan. "The Politics of Capitalist Diversity in Europe: Explaining Ireland's Divergent Recovery from the Euro Crisis." Perspectives on Politics. Forthcoming March 2017. Print.

Boal, Augusto. Theatre of the Oppressed. 1979. London: Pluto Books, 2008. Print.

Butler, Judith. "Performative Acts and Gender Constitution: An Essay in Phenomenology and Feminist Theory." Theatre Journal 40.4 (1988): 519-31. Print.

Cochrane, Kira. All the Rebel Women: The Rise Of The Fourth Wave Of Feminism. Vol. 8. London: Guardian Books, 2013. Print.

Crenshaw, Kimberlé. "Mapping the Margins: Intersectionality, Identity Politics, and Violence against Women of Color."

Stanford Law Review 43.6 (1991): 1241-99. Print.

Cullen Owens, Rosemary. A Social History of Women in Ireland, 1870-1970: An Exploration of the Changing Role and Status of Women in Irish Society. London: Gill \& Macmillan, 2005. Print.

Davies, Helen, and Claire O'Callaghan. "All In This Together? Feminisms, Academia, Austerity." Journal of Gender Studies 23.3 (2014): 227-32. Print.

Deane, Lughan and Patricia O’Mahoney. "Diversity Audit of Irish Front Pages." IMPACT. Impact.ie. Sept 30 2016. Web. Accessed Jan 102017.

Delphy, Christine. “A Materialist Feminism Is Possible.” Trans. Diana Leonard Feminist Review 4 (1980): 79-105. Print.

Evans, Sara Margaret. Personal Politics: The Roots Of Women's Liberation In The Civil Rights Movement And The New Left. London: Vintage, 1979. Print.

Fraser, Nancy. "Feminism, Capitalism, and the Cunning of History." New Left Review 56 (2009): 97-117. Print.

Faludi, Susan. Backlash: The Undeclared War Against American Women. New York: Broadway Books, 2009. Print.

Haughton, Miriam. "From Laundries to Labour Camps: Staging Ireland's 'Rule of Silence' in ANU Productions' Laundry.” Modern Drama 57.1 (2014): 65-93. Print.

Kershaw, Baz. The Radical In Performance: Between Brecht and Baudrillard. London: Routledge, 1999. Print.

Lefebvre, Henri. "The Production of Space." The People, Place, and Space Reader. Ed. Gieseking, Jen Jack, et al. New York: Routledge, 2014. Print.

Liddy, Susan. "Open To All And Everybody"? The Irish Film Board: Accounting For The Scarcity Of Women Screenwriters." Feminist Media Studies 16.5 (2016): 901-17. Print.

Lonergan, Patrick. "More Thoughts (and stats) on Women Writers at the Abbey." Patricklonergan.wordpress.com. Jan 22 2014. Web. Accessed Jan 102017.

- - . Theatre and Globalization: Irish Drama in the Celtic Tiger Era. London: Palgrave Macmillan, 2009. Print.

Mac Conghail, Fiach. "Personal Tweet." Twitter.com. 29 Oct 2015. Web. Accessed 10Jan 2016.

Maiguashca, Bice, Jonathan Dean, and Dan Keith. "Pulling together in a crisis? Anarchism, feminism and the limits of left-wing convergence in austerity Britain." Capital \& Class 40.1 (2016): 37-57. Print.

Martin, Jennifer L. “Ten Simple Rules To Achieve Conference Speaker Gender Balance.” PLOS Computational Biology 10.11 (2014): 1-3. Print.

Massey, Doreen. "Politics and Space/Time." New Left Review 196 (1992): 65. Print.

McAleese, Martin. "Report Of The Inter-Departmental Committee To Establish The Facts Of State Involvement With The Magdalen Laundries." Dublin: Department of Justice and Equality, Ireland (2013). Print.

McRobbie, Angela. The Aftermath Of Feminism: Gender, Culture And Social Change. London: Sage, 2009. Print.

Morash, Chris. A History Of Irish Theatre 1601-2000. Cambridge: Cambridge 
University Press, 2002. Print.

Mullally, Úna. "Abbey Theatre celebrates 1916 centenary with Only One Woman Playwright.” The Irish Times. 2 Nov 2016. Web. Accessed 30 May 2017. http://www. irishtimes.com/opinion/una-mullally-abbey-theatre-celebrates-1916-centenary-with-onlyone-woman-playwright-1.2413277

Murray, Christopher. Twentieth-Century Irish Drama: Mirror up to Nation. Syracuse: Syracuse University Press, 1997. Print.

Nield, Sophie. "There Is Another World: Space, Theatre And Global Anti-Capitalism." Contemporary Theatre Review 16.01 (2006): 51-61. Print.

O'Connor, Pat. Management And Gender In Higher Education. Oxford: Oxford University Press, 2014. Print.

Prasad, Aanand. "Conference Diversity Distribution Calculator.” Aanandprasad.com. N.d. Web. Accessed Jan 102016.

Regan, Aidan and Samuel Brazys. "Celtic Phoenix or Leprechaun Economics? The Politics of an FDI-led Growth Model in Europe." New Political Economy. 2017. Forthcoming.

Reingold, Beth. "Women as Officeholders: Linking Descriptive and Substantive Representation." Political Women and American Democracy. Ed. Christina Wolbrecht et al. Cambridge: Cambridge UP, 2008. Print.

Singleton, Brian. "ANU Productions and Site-Specific Performance: The Politics of Space and Place." That Was Us': Contemporary Irish Theatre and Performance. Ed. Fintan Walsh. London: Oberon, 2013. 21-36. Print.

Spillane, Alison. "The Impact of the Crisis on Irish Women." Ireland Under Austerity: Neoliberal Crisis, Neoliberal Solutions. Ed. Colin Coulter and Angela Nagle. Oxford: Oxford UP, 2015. 151-70. Print.

The Abbey. "Waking the Nation 2016 at the Abbey Theatre." Www.abbeytheatre.ie. Oct 2015. Web. Accessed 10 Jan 2017

-_—. "New Middle East." www.abbeytheatre.ie. 2016. Web. Accessed 30 Mar 2017.

The Economist. "Celtic Phoenix: Ireland Shows There is Economic Life after Death." The Economist. 19 Nov 2015. Web. Accessed 30 Mar 2017. http://www.economist.com/news/ finance-and-economics/21678830-ireland-shows-there-economic-life-after-death-celticphoenix

Walsh, Kathy, Jane Suiter and Órla O'Connor. “Hearing Women's Voices: Exploring

Women's Underrepresentation in Current Affairs Programming at Peak Listening Times in Ireland." National Women's Council of Ireland \& Dublin City University. Nov. 2015. Print. Wandor, Michelene. Understudies: Theatre and Sexual Politics. London: Methuen, 1981. Print. Ward, Margaret. "'Suffrage First, Above All Else!' fAn Account of the Irish Suffrage Movement." Feminist Review 10 (1982): 21-36. Print. 